\title{
FACTORS OF SERVICE QUALITY AFFECTING STUDENTS, AS CUSTOMERS, SATISFACTION OF RIDESHARING SERVICES IN VILNIUS, LITHUANIA
}

\author{
Jurgita Ginavičienè \\ Vilnius College of Technologies and Design, Lithuania \\ Indrè Sprogytè \\ Vilnius College of Technologies and Design, Lithuania
}

\begin{abstract}
Nowadays ridesharing has become crucial and extremely popular service. As modern consumers, students have become wiser and more rational, they tend to choose not only high quality transport but also they prefer desirable quality of transportation services. The main aim of this research is to identify the factors of service quality which have impact on customer satisfaction of ridesharing services in Vilnius, Lithuania. This study is an quantitative analysis. 124 students of Vilnius College of Technologies and Design Transport Logistics completed a questionnaire via apklausa.lt about factors which affect their evaluation of ridesharing services. Study participants filled out a questionnaire online and evaluate the importance of the values such as flexibility or speed on a 5-point Likert scale. According to the findings obtained, the opportunity to pay for transport by card, provided safety, reasonable price and comfort are significant factors in order to ensure customer satisfaction of ridesharing service.
\end{abstract}

Keywords: customer, evaluation, ridesharing service, satisfaction.

\section{Introduction}

The sharing services generate value for a consumer who is willing to pay for the services. The rapid growth of the ridesharing service shows that the appeal among consumers is self-evident. Reasonable price may not be major reason why consumers choose this service. The ridesharing services appear to compete with taxis for their increasing ubiquity as a convenient means of transportation. The ridesharing provides flexible transportation for anyone.

The aim of the article is to identify the factors which influence customers satisfaction of ridesharing services in Vilnius, Lithuania. The study focuses on students as customers.

In order to achieve a goal mentioned before the following tasks have been put forward:

1. Evaluate customers options of factors of ridesharing services which have impact on students satisfaction. 
Ginavičienè \& Sprogytè, 2020. Factors of Service Quality Affecting Students, as Customers, Satisfaction of Ridesharing Services in Vilnius, Lithuania

2. Present results of research on transport logistics students satisfaction of ridesharing services.

Literature review is beneficial in order to get specific knowledge of previous studies and essential analysis made in this field. This study is quantitative research and used method is the questionnaire survey.

The customers satisfaction of ridesharing services is the main element to explore the importance and necessity of ridesharing services, hence a quantitative research allows to compare students' opinions, as well as to identify the key factors of customer satisfaction of ridesharing service.

\section{Theoretical aspects of customer loyalty}

In the expanding global competition, new technologies came to place. Technologies have improved the relationship between consumers and businesses, thus increased customer expectations towards services. These changes in recent years have improved the satisfaction of users' needs and increased customers' loyalty.

Customers loyalty is vital for modern day business for two main reasons. Firstly, customers are scarce resource - it is more rational to hold an old customer than attract a new one (customer retention). Secondly, customer's loyalty has a positive effect on the profitability revenues of the company (Khadka \& Maharjan, 2017).

The consumers will always want to get a high-quality service that meets set expectations. If the customer, after the completion of service, is satisfied then repurchase becomes possible (Dudzevičiūtè \& Peleckienè, 2010). Customer loyalty is positively related to customer satisfaction.

Satisfied customers usually buy more. Besides buying more they also work as a network to reach other potential customers by sharing experiences (Khadka \& Maharjan, 2017). It means that customer satisfaction is a significant aspect talking about the success of ridesharing services.

According to Kotler and Keller (2006) satisfaction is an individual perception either they are satisfy or dissatisfy based on their expectations towards product or service performance. In line with the definition, customer satisfaction reflected from the disconfirmation theory of customer expectation, while a positive disconfirmation leads to satisfaction and negative satisfaction leads to dissatisfaction (Oliver, 1980; Reianu, 2014).

Consumer behaviour - a behaviour related to the satisfaction of receiving service, which is sought, ordered, used, and disposed, as well as the opinion formation about the delivery of the service. Changes in consumer behaviour is formed with influence of various factors. 
Shifts in consumer behaviour are mostly influenced by the search and evaluation costs, price, quality, and the service that is provided on time and in place (Ginavičienė \& Sprogytè, 2016).

The ridesharing services companies must ensure that it will be taken care of the customers' needs and expectations.

In addition, the modern technology available to the firms also supports the individualistic attitude toward customers. In most of the services, direct contacts with customers give a good starting point for the individual treatment of the customers (Grönroos, 2007).

\section{Influence of customer satisfaction on the ridesharing services}

Broadly speaking, customer loyalty is a behaviour while customer satisfaction is an attitude. Generally, price, quality, reliability, empathy, responsiveness are the main factors that influence both the customer satisfaction and loyalty (Khadka \& Maharjan, 2017). This means that all criteria are taken into account when selecting a service. Therefore, there are certain differences between the factors which influence customer satisfaction and customer loyalty (Gajjar, 2013).

Product quality, price, service, consumer's emotion, personal factors, situational factors, a perception of equity or fairness and product features are the factors that have impact on the customer satisfaction. Customers expect the high quality of service through retailers, thus the service marketers have to assess how customers perceive the quality of the "services feature" implied by the perceived service quality framework (Khadka \& Maharjan, 2017).

Service quality is influenced by perceived service and expected service. If the perceived service is less than the expected service, the customer will be disillusioned; but, on the other hand, if the perceived service is more than the expected service, the customer will be satisfied (Abd Elmeguid et al., 2018).

The possible dimension to measure customer satisfaction could be quality, price, trust relationship, complaints and problems. First of all, to maintain a relationship, the service has to fit the customer's need. Designing for relationships requires a customer orientated approach. Maintaining customer relationship just do not happen accidentally, they are constructed through the service and product provided. Today, the customers demand flexibility, availability, creativity and price advantages from the service provider (Khadka \& Maharjan, 2017).

While private companies are mostly interested in measuring customer satisfaction in order to maintain an advantage over opponent players on the market, the major benefits of public institutions from measuring customer satisfaction emerge from the improvement in the quality of services that they are 
Ginavičiene \& Sprogytè, 2020. Factors of Service Quality Affecting Students, as Customers, Satisfaction of Ridesharing Services in Vilnius, Lithuania

offering, and an efficient way to do it by reducing costs and expenditures. Also, a higher confidence in public institutions is one of their objectives in a long run (Reianu, 2014).

Zeithaml et al. (2006) stated that tangibles like safety and convenience for customers are representative as a company's image and quality. As aforementioned some empirical studies proved that tangible has influence on customer satisfaction in overall.

As Husseni (2016) studied the relationship between service quality and customer satisfaction in the taxi companies in Nairobi Researchers found that service quality influences satisfaction of customer.

Following study by Horsu and Yeboah (2015) research on customer satisfaction towards minicab taxi services in Ghana. They used six variables namely reliability, continuous service, safety, comfort, affordability and drive behaviour. Variables were tested to examine the relationship with customer satisfaction. Through multiple regressions analysis they found that continuous service, comfort, affordability and reliability have a significantly positive influence on customer satisfaction.

Khuong and Dai (2016) found that reliability, responsiveness, price and satisfaction directly affected customer loyalty.

According to Litman (2008), the availability of service such as seats, space, journeys, and air conditioning directly affect service comfort.

Ride delay (duration difference between actual and direct ride times) and waiting time (duration difference between desired pick-up time and the time when the customer is actually picked up) also may be considered as important factors while analysing customer satisfaction.

In transportation, one of the contributing factors of customer satisfaction is personal security. Any anticipation of negative behaviour can affect all characteristics of travel options, which may include the mode, time of day; route to be taken etc. and it also force a person to not travel at all (Abd Elmeguid et al., 2018).

As per reviewing the literature, it was found that there are many factors that affect customer satisfaction and they vary according to the type of service provided as well as the culture of the geographical location that the service is allocated in it (Khadka \& Maharjan, 2017).

As ride sharing service becomes important and inevitable nowadays, this research is designed to explore the factors achieving customer satisfaction regarding the service under study. 


\section{Customer satisfaction of the ridesharing services in Vilnius, Lithuania}

As Balachandran \& Hamzah (2017) stated that one of the advantages by conducting survey through email or internet is that this way is faster and more convenient than telephone interview. Due to this reason, in this research used method was a survey online.

The study took place in 2019. 124 students of the Vilnius College of Technology and Design study program Transport logistics participated in this research.

Survey sampling bias is calculated according to the Paniott formula:

$$
n=\frac{1}{\Delta^{2}+\frac{1}{N}},
$$

where $\mathrm{n}$ - sample size,

$\Delta^{2}$ - bias probability,

$\mathrm{N}$ - Research totality, that ensures approximately 5\% probability of bias.

After the evaluation of the study sample bias, it was found that the minimum number of respondents should be 123 , the number of respondents in this research was 124 students.

Data collection method - a questionnaire survey, which was carried out electronically, through www.apklausa.lt and sent to the students via their personal e-mails.

Questionnaire items were compiled structured, containing response options. Most issues have been concluded using the Likert scale, as more useful information for the investigation can be collected in response to these types of questions.

The study was aimed to identify the factors of service quality which have impact on customer satisfaction of ridesharing services in Vilnius, Lithuania.

Total respondents were 124 students (1-4 course) who study in Vilnius College of Technologies and Design, in Transport Logistics program 2019-2020 and who were willing to complete a survey. Both genders participated in the study. It was 86 male respondents (70\%) and 38 female respondents (30\%).

The majority of respondents were aged between $18-23$ years old $(82.2 \%)$. The second smaller age group of respondents were between 24-30 years old (7.3\%) and similarly the third age group of respondents were 31- 40 year old (7.2\%). Finally the smallest group are until 18 years old together with ones above 40 years old (only 1.6\%). The data would seem to suggest that $18-23$ years old respondents were the most willing to use ridesharing services. It can be explained by mentioning that 18-23 years young people are not enough 
Ginavičiene \& Sprogytè, 2020. Factors of Service Quality Affecting Students, as Customers, Satisfaction of Ridesharing Services in Vilnius, Lithuania

financially stable (financial dependency from parents, student loans, etc.). Student may be try to find best solution considering price and quality of affordable transportation service but further research should be done in order to support these statement.

Income analysis shown that the majority of respondents is between less than $380 €(41.1 \%)$, the second are $301-500 €(21 \%)$, the third rank is $501-700 €$ (14.5\%), the fourth rank is $701-1000 €(13.7 \%)$. The fifth rank is $1001-1500 €$ (7.3\%). The smallest rank is more than $15001 €(2.4 \%)$. Statistically speaking students who income is less than $380 €$ are more willing to choose ridesharing service in comparison with others.

The ridesharing users were using Bolt (50.6\%) service more than Etransport (12.6\%) or Uber (12.6\%). It means most of the ridesharing users prefer to use Bolt not Etransport or Uber. The reason is the affordable price and the conveniency.

It is important to notice frequency of using ridesharing service. 68 of respondents (54.8\%) use the service less than one in a month. Meanwhile, 31 respondents (25\%) were using ridesharing services in 5 times or less in a month and 17 respondents $(13.7 \%)$ are using this services' one in a month. 6 respondents (4.9\%) were using ridesharing services in 5 times or less in a week and 2 respondents (1.6\%) are using services for every day. According to statistics, the most popular answer was using ridesharing service less than one time in a month.

Respondents were asked what type of payment is more acceptable (Fig.1)

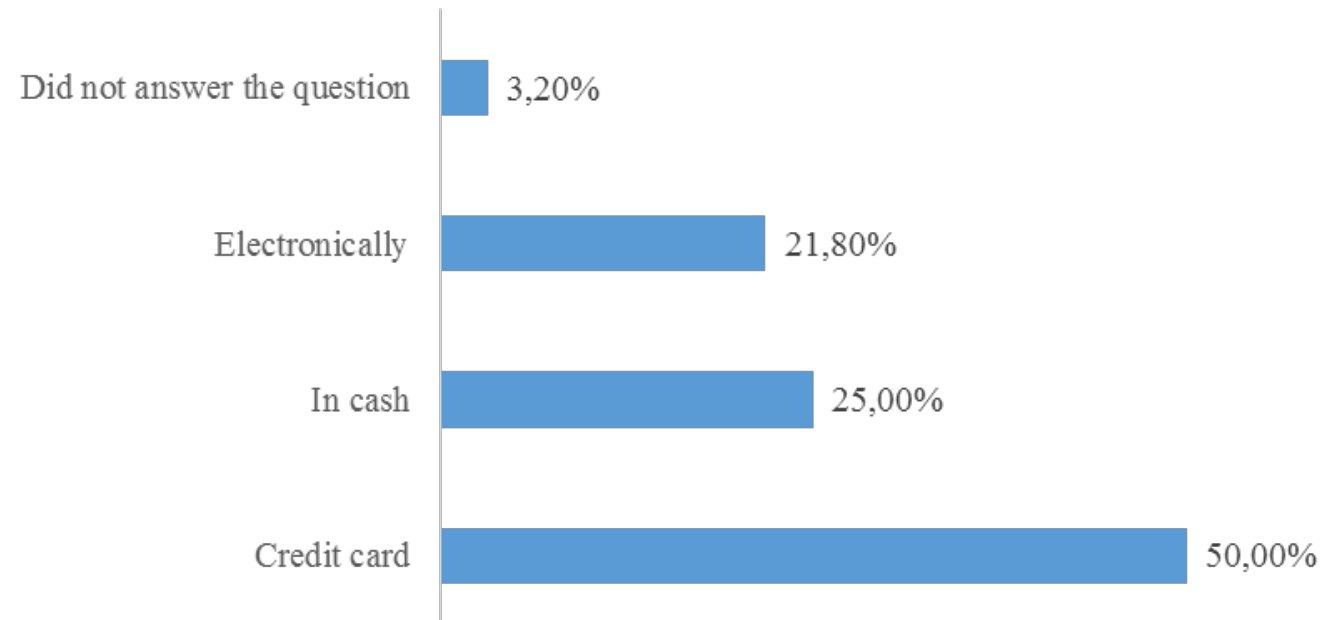

Figure 1 The types of payment (created by the authors)

50 respondents (50\%) said that the most acceptable type of payment is paying by credit card. 25 respondents (25\%) said that paying in cash is more convenient type of payment. 
Respondents were asked to evaluate criteria why they choose ridesharing service (Fig.2). Evaluation of criteria was based on 5 scale Likert scale measurement (1 - not important at all, 2 - does not matter, 3 - partly important, 4 - important, 5 - very important). All calculations and conclusions about students' evaluation of ridesharing service were made paying attention only to the highest value of this scale (only to 5).

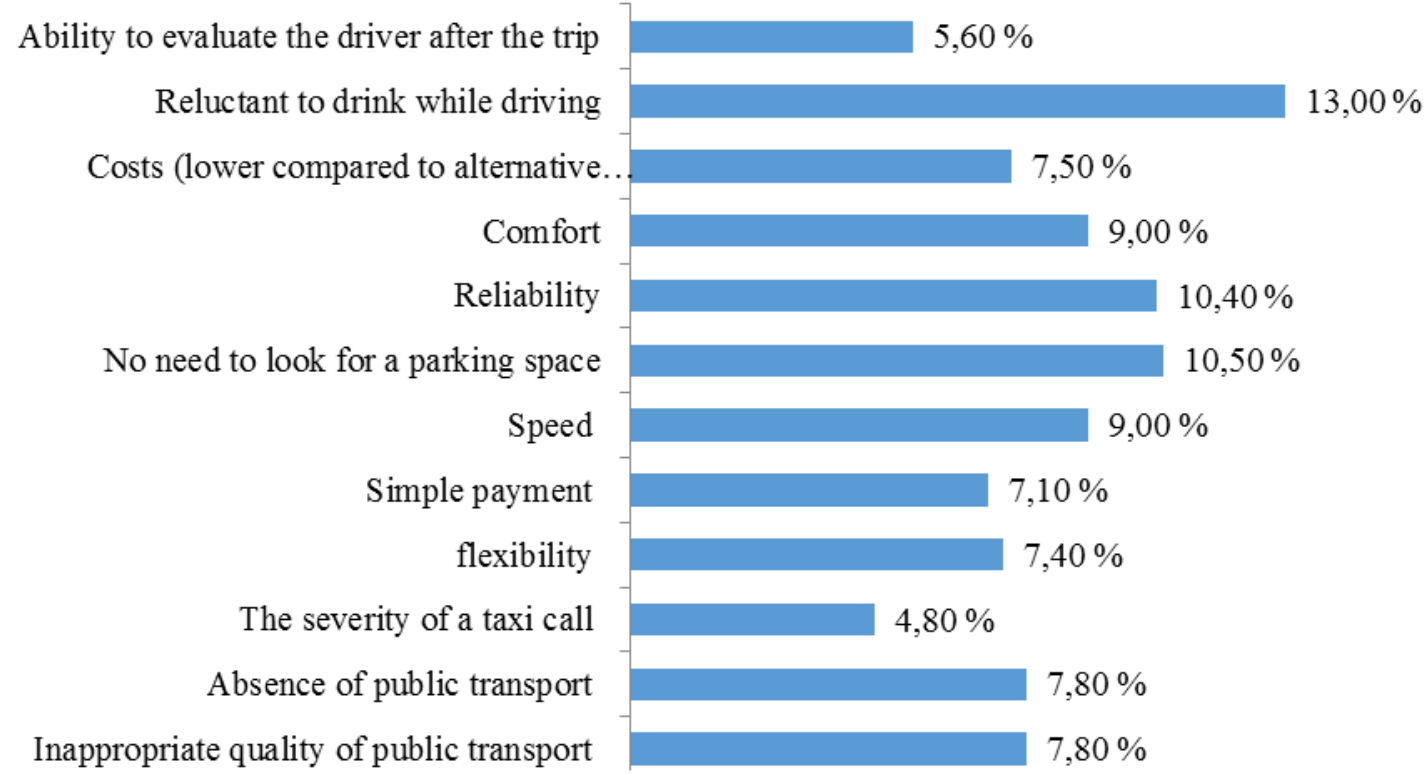

Figure 2 The ridesharing services using criteria (created by the authors)

Respondents had (Fig. 2) to evaluate the criteria's in accordance to importance. The ridesharing services users mentioned that one of the most popular reason to choose such services is not wanting to drive drunk (12.95\%). The second reason to not waste time by looking for parking space for the own car (10.54\%). It was relevant because lot of respondents are using ridesharing services for going to the city centre. The third is reliability (10.39\%). Unpopular answers were the severity of a taxi call (4.82\%) and the ability to evaluate the driver after the trip (5.57\%).

After the literature review it became clear that the most influential factor of customer satisfaction is the comfort. Respondents were asked to evaluate criteria's (Fig.3) based Likert scale measurement (1 - not important at all, 2 - does not matter, 3 - partly important, 4 - important, 5 - very important). 
Ginavičienè \& Sprogytè, 2020. Factors of Service Quality Affecting Students, as Customers, Satisfaction of Ridesharing Services in Vilnius, Lithuania

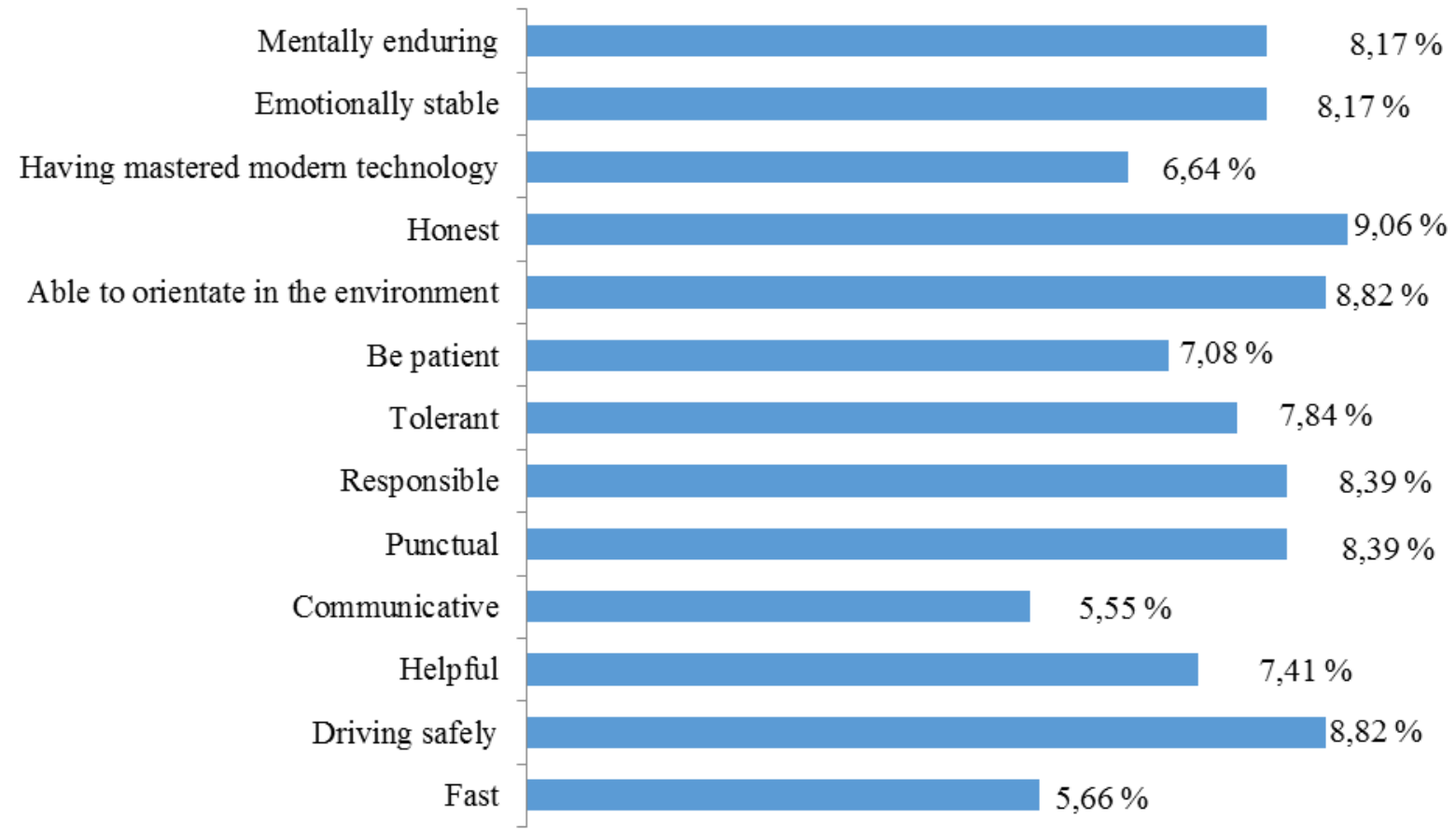

Figure 3 The ridesharing driver's criteria's (created by the authors)

The results showed that the most important driver's criteria's are honesty (9.6\%), safety while driving (8.82\%), the driver's ability orientate in the environment (8.82\%), punctuality (8.39\%) and responsibility (8.39\%). Less remarkable for the ridesharing driver's criteria's are communicative (5.55\%) and going fast (5.66\%). It means most of the ridesharing services drivers must drive safely, orient in roads, be punctual and responsible.

It was found that the most influential factor of customer's satisfaction is the comfort. Students choose ridesharing in order to reach home safely instead of driving drunk, avoid thinking where to park their car and because of reliability.

It is crucial to emphasize that according to this research, payments should be made by credit card.

In the contemporary global market conditions, meeting the consumer needs is mandatory. This is confirmed by the results of students ' opinion empirical research. The survey shown that Lithuanian the ridesharing services companies in competition with each other and comparing their own activities, indicate taking into account the customers' wishes and responses are the main factors of the competitive advantage.

\section{Conclusions}

Nowadays the ridesharing becomes important service. Ridesharing companies are trying to get clear indicators that their investment in customer 
satisfaction is worth the risks and will provide good results. From this point of view, the measuring of customer satisfaction became an important tool. Reliability, quality, price, service, service comfort, consumer emotion, personal factors, situational factors, a perception of equity or fairness, product features are the factors that influence the customer satisfaction.

According to the survey, we found that the most influential factor of customer satisfaction is the comfort and reliability. Ridesharing service is an alternative in order to avoid driving drunk or avoid thinking about where to park a car. It is hard to deny that ridesharing service appears the most attractive for $18-23$ years students and for ones who income is less than $380 €$.

The students' opinion research showed that customer satisfaction is the applied factor of Lithuania ridesharing services increasing their advantage. However further researches should be made in order to formulate more precise conclusions.

In the contemporary global market conditions, meeting the consumer needs is mandatory. The survey shown that Lithuanian the ridesharing services companies in competition with each other and comparing their own activities, indicate taking into account the customers' wishes and responses.

\section{References}

Abd Elmeguid, S.M., Ragheb, M.A., Tantawi, I.P., \& Elsamadicy, A.M. (2018). Customer satisfaction in sharing economy the case of ridesharing service in Alexandria, Egypt. The Business and Management Review, 9(4), 373.

Balachandran, I., \& Hamzah, I.B. (2017). Influence of customer satisfaction on ride-sharing services in Malaysia. International Journal of Accounting \& Business Management. 5(2), 187-196. Retrieved from http://www.ftms.edu.my/journals/pdf/IJABM/Nov2017/ 184-196.pdf

Dudzevičiūtè, G., \& Peleckienė, V. (2010). Marketing strategy process: quantitative analysis of the Customers' satisfaction. Verslas: Teorija ir praktika. Business: Theory and practice, 11(4), 345-352. DOI: https://doi.org/10.3846/btp.2010.37

Gajjar, B.N. (2013). Factors Affecting Consumer Behavior. International Journal of Research in Humanities and Social Sciences, 1(2), 10-15.

Ginavičienè, J., \& Sprogytè, I. (2016). Competitiveness of transport companies in the opinion of student. Society. Integration. Education. Proceedings of the International Scientific Conference. Volume IV, May 27th-28th, 288-299. DOI: http://dx.doi.org/10.17770/sie 2016vol4.1562

Grönroos, C. (2007). Service management and marketing. Third edition. John Wiley \& Sons, Ltd. England.

Horsu, E.N., \& Yeboah, S.T. (2015). Influence of Service Quality on Customer Satisfaction: A Study of Minicab Taxi Services in Cape Coast, Ghana. International Journal of Economics, Commerce and Management, III(5), 1-14. Retrieved from http://ijecm.co.uk/wp-content/uploads/2015/05/3595.pdf 
Ginavičienè \& Sprogytè, 2020. Factors of Service Quality Affecting Students, as Customers, Satisfaction of Ridesharing Services in Vilnius, Lithuania

Hussein, A.A. (2016). Service Quality Practices and Customer Satisfaction in Taxi Companies in Nairobi. Master's Thesis - Business Administration in Operations Management, School of Business, University of Nairobi. Retrieved from http://erepository.uonbi.ac.ke/bitstream/handle/11295/99277/Service\%20Quality\%20an d\%20Customer\%20Satisfaction\%20in\%20Taxi\%20Companies.pdf?sequence=1\&isAllo wed $=\mathrm{y}$

Khadka, K., \& Maharjan, S. (2017). Customer satisfaction and customer loyalty. Thesis, 73. Retrieved from https://core.ac.uk/download/pdf/161421179.pdf

Khuong, M.N., \& Dai, N.Q. (2016). The Factors Affecting Customer Satisfaction and Customer Loyalty - A Study of Local Taxi Companies In Ho Chi Minh City, Vietnam. International Journal of Innovation, Management And Technology, 7, 5. 228-233. DOI: 10.18178/ijimt.2016.7.5.678

Kotler, P., \& Keller, K. (2006). Marketing Management, 12th Edition, Pearson Education Inc., New Jersey.

Litman, T. (2008). Valuing Transit Service Quality Improvements. Journal of Public Transportation, 11(2), 43-64. Retrieved from https://www.researchgate.net/publication/ 252745569_Valuing_Transit_Service_Quality_Improvements

Oliver, R. (1980). A Cognitive Model of The Antecedent and Consequences of Satisfaction Decisions. A Journal of Marketing, 17(10), 460-469.

Reianu, D.G. (2014). Analysis of customer satisfaction in case of the day center for the elderly, cluj-napoca city hall. Transylvanian Review of Administrative Sciences, 41, 170-189. Retrieved from https://www.researchgate.net/publication/260807584_ Analysis_of_Customer_Satisfaction_in_Case_of_the_Day_Center_for_the_Elderly_Clu j-Napoca_City_Hall

Zeithaml, V.A., Bitner, M.J., \& Gremler, D.D. (2006). Services Marketing: Integrating Customer Focus Across The Firm (4th Ed). Singapore: Mcgraw-Hill. 